\title{
Investment Policy of the European Union. Empirical Evidence of the Effects of Foreign Direct Investment on The European Union Economy
}

\author{
Corneliu Russu \\ Centre for Industry and Services’ Economy, Romanian Academy, 125 Calea Victoriei, Sector 1, 010071, \\ Bucharest, Romania \\ e-mail: corneliu_russu2007@yahoo.com
}

DOI: 10.51865/EITC.2021.01.01

\begin{abstract}
The paper deals with the evolution during a period of over 60 years of the investment policy of the European Union, pointing out the main moments that marked the steps taken towards the progressive shaping of an increasingly unitary character of this policy. The increase of the interest of foreign investors for strategic, sensitive sectors of the economy of the member countries determined, after 2017, a change in the philosophy of establishing and applying the Union's investment policy, materialized in the more precise definition of "foreign investor" and in implementing a more rigorous mechanism of control of foreign direct investment. Further on are presented the main effects of foreign investment in the Community economy, resulting from empirical studies on this topic, the conclusions reached by these studies being sometimes divergent.
\end{abstract}

Keywords: investment policy; foreign direct investment; investor.

JEL Classification: L52; O16.

\section{Introduction}

The intensification of the globalization process is taking place in parallel with the international movement of capital that has dramatically accelerated in recent decades, within the latter foreign direct investment - FDI, as a component of capital flows, experiencing the fastest amplification. However, the distribution of capital flows in the world is very uneven, with an extremely wide dispersion of foreign capital sources and investment intensity between countries.

The European Union is one of the most important players in the world FDI flows, both as a destination and as a source of these flows, significantly benefiting from the effects of the substantial inflows it has absorbed over the years, and also recording massive outflows throughout world. 


\section{Progressive Crystallization of the Unitary Investment Policy of the European Union}

The European Union has outlined its foreign investment policy relatively late, given that it has a complex multinational structure, and the response to the requirement to harmonize Member States' investment regimes, which has been consolidated over several decades, has proved to be a particularly difficult approach.

The shaping of an investment policy of the Community as a whole can be considered to have begun with the adoption of the Treaty of Rome in 1957, establishing the European Community, which enshrined the creation of the common market as an essential element of the economic integration of member countries, which involved the adoption of the freedom of movement of goods, services, labor and capital, the establishment of the customs unit, and the initiation of financial policies on competition and investment common for the Member States.

From these initial general provisions it passed subsequently to increasingly rigorous regulations, able to stimulate FDI and to amplify its beneficial effects on the Community economy.

The Single European Act of 1986 stipulated for the liberalization of capital transfers and the removal of existing barriers between Member States, i.e. only within the European Community.

The Maastricht Treaty, which established the creation of the European Union in 1992, removed all restrictions on foreign investment, both in terms of inflows and outflows of investment.

The Energy Charter Treaty, adopted in 1995 and entered into force in 1998, stipulated for, inter alia, measures to protect investments in energy resources in Eastern Europe. The treaty also contained provisions on taxation, trade, environmental protection, competition rules. According to the Treaty, investment protection is ensured through fair and equitable treatment of all stakeholders, protection against illegal expropriations, freedom of capital transfer, compliance with the national treatment mechanism and the most favorable treatment rule, the right of investors to use labor regardless of nationality.

Until 2009, the area of investment protection was the sole responsibility of the Member States' authorities, which could freely conclude bilateral investment agreements within and outside the Union; This has led to a multitude of national regulations and standards on investment protection, most of them following the OECD model for concluding international investment treaties (OECD, 1962). The Common Trade Policy was the responsibility of the Union's central bodies, and the FDI policy remained at the discretion of the Member States, although both policies interfered deeply; implicitly, some provisions of international investment treaties concluded by member countries have proved to be inconsistent with the legal provisions of the Union.

The entry into force of the Treaty of Lisbon in 2009 (Treaty of Lisbon Amending the Treaty on European Union and the Treaty Establishing the European Community, 13 December 2007) produced a profound change in Community investment policy through the passage of the Common Commercial Policy, and implicitly of investment policy, under the sole decisionmaking responsibility of the Union, in accordance with the provisions of Article 3 of the Treaty, which stipulates the Union's right to negotiate and conclude international agreements and to establish investment protection obligations on behalf of Member States. From the date of entry into force of the Treaty, at the conclusion of any bilateral trade and investment agreement, Member States are required to seek the approval of the Union's central bodies.

Under the new conditions created by the provisions of the Treaty, negotiations between the European Union and the United States of America for the conclusion of the Transatlantic Trade and Investment Partnership Treaty - which, at the time of its entry into force, it covered almost one third of the value of world trade -, have continued. The coordinates of this treaty were also 
found in those subsequently concluded with Canada and East Asian countries. At the same time, bilateral trade and investment agreements concluded by member countries have been gradually replaced by new agreements engaged and signed by the Union.

The new course of the European Union's investment policy has generated disputes between the European Parliament - whose position was in favor of maintaining a certain autonomy of member countries in investment decisions by restricting the rights of foreign investors -, and the European Commission - which advocates extending protection of foreign investors in Member States in balance with ensuring the same protection regime for Community investors outside the Union. Finally, the Commission's position prevailed, the prerogative to conclude investment protection agreements being valid for foreign direct and portfolio ones.

A new regulation that came into force in 2012 - European Parliament and the Council. Regulation (EU) No. 1219/2012 of 12 December 2012 establishing transitional arrangements for bilateral investment agreements between Member States and third countries - stipulates for that the European Commission has to carefully examine existing and new bilateral trade agreements initiated by Member States in order to check whether it complies with the provisions of Community law; according to this regulation, bilateral investment agreements

initiated after 2009 must be authorized by the European Commission to open formal negotiations. The regulations adopted after 2009 highlight the efforts made towards the progressive implementation of a unitary investment policy of the European Union, based on the idea of acquiring a superior bargaining power in relations with foreign investors willing to invest in member countries and non-EU host countries targeted by investment made by Community companies.

The European Union's approach to protecting FDI has become clearer following the publication of a paper on the results of the public consultation on this issue in 2014. The key standards that reflect the new coordinates of the approach are the following:

o states have the exclusive right to regulate in specific or sensitive areas such as national security, health, education and protection, environmental protection, etc., provided that the application of public policies does not discriminate in respect of the rights of foreign investors;

o fair and equitable treatment, a rule present in almost all international agreements on investment flows, and which means ensuring appropriate processes in the event of litigation, avoiding arbitrariness, discrimination and coercion, and the obligation to act in good faith;

o full protection and security of investors and investments, under which host countries are obliged to take appropriate measures against any interference by police, demonstrators, etc. in disputes with investors, according to international standards of protection regardless of national rules;

0 adoption and maintenance by the host country of prudential measures aimed at ensuring the stability of the financial system and preventing financial destabilization, which are indispensable in the event of a state of financial crisis, external financial difficulties etc. ;

0 prohibiting the taking over of favorable provisions from other agreements, such as the use for one's own benefit of the most advantageous clauses stipulated in them;

0 inclusion of the arbitration mechanism of the investor - State litigation in all future International Investment Agreements; this mechanism must ensure: the prevention of unfounded claims and the avoidance of parallel claims in two different arbitration tribunals; establishing the obligation for the losing party to administer the procedural costs for both parties; limiting the amount granted for financial damages to the investor; ensuring public transparency of judicial proceedings; ensuring the rigorous control of the appointment of judges - arbitrators and of the conduct of the arbitration process. 
A regulation to clarify the division of financial responsibility between the European Commission and Member States in resolving investor-State disputes was adopted in August 2014 (European Commission, 2014), which establishes three principles: the rule of budget neutrality, according to which the cost of arbitration is not paid from the Community budget when the treatment in question has been granted by a Member State and not required under Union rules; the priority of the investor's financial interests, under the conditions of which disagreements between the Union and the Member States over financial responsibilities must not affect the investor's right to obtain a sentence of the arbitration tribunal; the obligation of sincere cooperation between the Union and the Member States in all stages of the judicial proceeding.

In 2015, the European Commission published a document (European Commission, 2015) replacing the Investor-State Dispute Settlement mechanism in all European Union negotiations on current and future investments with the Investment Court System; it stipulates the protection of the right of the European Union and the Member States to lay down specific rules so as to ensure that Union firms and foreign investors in the Union are protected against any form of illtreatment. The tribunal - which will consist of 15 judges from the European Union, the US and third countries - will hear the parties only on the basis of the provisions of the Transatlantic Treaty. Provision is made for the possibility of mediation prior to the formal dispute settlement procedure and the recourse to a Court of Appeal similar to the Court of Appeal (WTO Appellate Body). The Court of Appeal was a temporary solution, the European Commission aiming to set up a permanent International Investment Tribunal, for taking over all investment dispute settlement mechanisms under European Union agreements.

In the light of the latter regulations, the investment policy of the European Union has acquired a unitary and flexible character, pursuing two essential objectives:

0 increase the attractiveness of member countries for foreign investors based on clear regulations to protect their rights;

o protecting the rights of European Union investors abroad by respecting the principle of reciprocity.

\section{A Significant Change in the Union's Investment Policy after 2017}

Recently, there has been a growing concern in the Member States about the interest of foreign investors in strategic, sensitive sectors of their economies, materialized in FDI made, in particular, by non-transparent state-owned companies in strategic sectors and technologies.

Given that FDI stocks accumulated by third-country investors in the European Union totaled 6441 billion euro at the end of 2017 and provided about 16 million jobs, and in order to protect member countries' strategic interests in foreign investment, the European Commission proposed in September 2017 a regulation establishing a framework for FDI control in the European Union. Based on this preliminary document, the Commission issued a regulation in March 2019 which:

o provides for the creation of a new database showing the real situation of the foreign properties of the companies in the Union (given that the available statistics on FDI did not allow the secure identification of the last owner with the detailed breakdown by business sectors);

o emphasizes the particular importance of foreign investment for the EU (in the sample analyzed, $3 \%$ of companies were owned or controlled by non-EU investors, who owned more than $35 \%$ of their assets and had more than 16 million jobs);

o points out that the main traditional investors, coming from developed countries, control over $80 \%$ of the total foreign-owned assets; 
o notes the very dynamic emergence of "new investors in emerging markets and offshore financial centers, especially China, whose investments and acquisitions are concentrated in several subsectors" (e.g. China in aircraft production and specialized equipment, India in pharmaceuticals, etc.);

0 shows that foreign ownership is in key sectors of the economy - crude oil processing $(67 \%$ of assets), substances and pharmaceuticals (56\%), electronic and optical products (54\%), insurance (45\%), electrical equipment ( $39 \%$ );

o notes that public companies have a modest share in foreign acquisitions, but that the number of asset acquisitions has increased significantly in recent years, including those made by people and families with passports from different countries;

o notes the "financialisation" of FDI in the sense that foreign investment funds and companies with capital equity (derived from the sale of stocks) are present in a large number of acquisitions.

This regulation, which did not set up the adoption of a FDI control mechanism capable to allow the European Commission to block foreign investment that does not comply with Community rules, was followed by another (European Commission, 2017) aimed at "establishing a mechanism for cooperation between Member States and Commission for mutual information on FDI that may threaten security or public order and the exchange of information in this regard".

The document highlights the correspondence of the envisaged mechanism with the provisions of existing policies in this field, as well as with other European Union policies (on free movement of capital and freedom of establishment, mergers, energy, raw materials, cyber security and electronic communications, air transport, prudential assessment, procurement in the financial sector, dual-use export control, European space policy).

For making operational the control mechanism, a Guide for Member States (European Commission, 2020a) was subsequently developed, which also takes into account the effects of the COVID-19 on the economy of the European Union and provides for its entry into force on 12 September 2020. The mechanism stipulates (European Commission, 2020b):

o notification by the European Commission of member countries regarding their own existing investment control mechanisms;

o establishing formal contact points and secure communication channels in each member country and within the Commission for the exchange of information and analysis;

o establishing procedures for Member States and the Commission to respond quickly to FDI concerns and to publish opinions on the topics discussed; updating the list of projects and programs of interest to the Union.

In Romania, before the date of entry into force of the new mechanism, there was, for reasons of national security, a control system of FDI on transactions in some economic fields, according to the provisions of Competition Law no. 21/1996, which provided that upon notification of the Competition Council, the Supreme Council of National Defense analyzes operations that may affect national security and, if necessary, blocks them (in areas such as security of citizens and communities, security of resources critical infrastructure, information and communication systems, financial, banking and insurance activities, protection of agriculture and the environment, privatization of public enterprises or their management).

According to the Draft of Government Emergency Ordinance that is in line with the provisions of the European FDI control mechanism (Guvernul României, 2019), put up for public debate and scheduled to enter into force on October 11, 2020, are notified to the Competition Council FDI that have a value of at least the equivalent in lei of 2 million euro and whose object of activity falls into one of the areas stipulated by the Supreme Council of National Defense in the Decision no. 73 / 13.09.2012; other FDI may also be examined if it is considered that they may affect national security or public order. The definition of FDI formulated in the FDI Regulation 
is also extended to investments that allow the foreign investor to obtain, through the economic entity in which he invests, access to relevant information, technologies and systems that may affect the security or public order of the country.

The definition of foreign investor is broadened to include, in addition to natural or legal persons from a third country, legal persons having their registered office in a member country of the European Union, controlled, directly or indirectly, by a natural person, a legal person or an entity without legal personality from a third country, as well as the financial administrators of an entity without legal personality or persons in a similar position, if they are not natural or legal persons from the European Union.

The FDI control mechanism provides for the following procedures: notification by the foreign investor or by the parties involved in a merger of the Competition Council, regardless of whether or not the FDI in question is an economic concentration; the Competition Council forwards the notification to the Commission for the examination of FDI (CEFDI), which must complete it within a maximum of 45 days from the date on which the notification became effective (when it was registered by the Competition Council); when the CEFDI considers that there are major security risks or when the votes of the members of the Commission do not meet the majority required to issue the assent, the Competition Council requests the opinion of the Supreme Council of National Defense, which must be issued within 90 days from its request; after examining the opinion, the CEFDI issues an assent for the authorization, followed by a decision of the Prime Minister of conditional authorization, prohibition or cancellation of the FDI. Non-compliance with the obligation to notify an FDI or providing inaccurate, incomplete or misleading information constitutes a contravention, punishable by the Competition Council with a fine of $1 \%$ to $5 \%$ of the total turnover in the financial year preceding the sanction.

Within the framework of the cooperation mechanism at European Union level, CEFDI publishes on the website dedicated to the evaluation of foreign investments, elaborated in four languages, all the decisions regarding these investments; the Competition Council notifies the European Commission and the other member countries of the initiation of procedures for the verification of those investments; the Competition Council forwards to CEFDI the observations of the member countries and the opinions of the European Commission, received in accordance with that Regulation, and notifications regarding FDI verification received from other member countries; the Competition Council transmits CEFDI comments concerning an FDI from another member country.

The provisions of the Ordinance do not apply to portfolio investments.

\section{Effects of FDI on the Economy of the European Union. Empirical Evidence}

The massive inflows of FDI absorbed over time by the European Union have had significant effects on its economy, which has been the subject of a number of researches much smaller than that dedicated to developing countries. The favorite topic addressed in studies on the European Union is the influence of FDI on the economic growth of the whole community or on groups of countries, especially the group of Central and Eastern European countries, that have gone through the process of transition from a centrally planned economy to a market model, the impact of FDI on the economy of these countries being more substantial and easier to highlight. Other plans on which the effects of FDI were studied were those of export, technological diffusion, human capital, environmental protection.

A. Mondatson analyzed the effects of FDI on economic growth in the European Union and highlighted their positive nature, both directly and indirectly, by increasing the volume and value of exports and improving its structure (Mondatson, 2003). The period analyzed was 1980- 
1996 and estimates were made by country and by the Union as a whole. The determinants of FDI growth vary significantly from country to country, a conclusion that is anticipated but strongly supported by scientific reasoning. Another interesting conclusion is that the economic growth effect of FDI does not depend decisively on the level of human capital existing in developed countries, unlike the situation existing in this respect in developing countries.

D. Tang's research focused on the effects of foreign capital inflows into the European Union between 1987 and 2012, and concluded that higher FDI inflows and foreign portfolio investment, impelled by the European Monetary Union after 1999, did not positively influenced economic growth (Tang, 2015). The author demonstrates that if the inflow of total capital has not had an effect on economic growth, the interaction between FDI and the financial development of host countries has, on the contrary, a positive impact, which in the long run argues for intensified efforts to attract these investments. The explanations are many: the development of the banking system and the stock market have opposite effects on economic growth, in the sense that bank credit flows have slowed growth and the capitalization of the stock market has boosted it (increasing the size of the stock market and the introduction of the euro have greatly increased the potential financing of domestic investments, which stimulated growth); the interaction of FDI with the development of the banking system affirms its longterm positive effects, a process that can be accelerated by the gradual integration of the banking system in the European Union, which will ensure its positive and influence on economic growth.

The correlation between the inflow of FDI and the growth of the European Union's GDP was analyzed by Sonia Milutinovič and Tanya Stanišić in the period 2005-2015, so over 11 years (Milutinovič, Stanišić, 2016). The descriptive statistics of GDP and the analysis of its growth rate during that period show that there was a minimum rate of -4.39 in 2009 , in the midst of the global crisis, and a maximum rate of 3.39, throughout the mentioned period the average rate of increase being 1.05. The initial hypothesis of the analysis was that the inflow of FDI has a positive effect on Community GDP growth. The calculation of the Pearson correlation coefficient between these two variables during the analyzed period led to the conclusion of the existence of a negative interdependence between them (value of the coefficient: -0.031). The analysis of the simple regression coefficient confirmed the conclusion that there is no positive effect of the FDI inflow on GDP, implicitly on the economic growth of the European Union, contrary to the initial hypothesis.

The effects of the influx of FDI on the economies of Central and Eastern European countries that became members of the European Union after 2004 were also a topic addressed by researchers. S. Estrin's study is dedicated to these countries, but also to others rich in resources such as the Russian Federation and those in the Central Asian region (Estrin, 2017). Central and Eastern European countries were, during the centrally planned economy, isolated from the world economy and international FDI flows, which prevented them to benefit from technological progress registered in other countries. Their acute need for capital to increase their competitiveness and to fit effectively into the world economy made the FDI inflows they absorbed after 1989 to be massive, especially through privatizations, mergers and acquisitions. However, the effects of FDI were very varied between countries, mainly due to the differences between the development strategies and policies applied and the quality of the institutional frameworks.

Although the positive effects of FDI have been significant on economic growth, labor use, productivity and export competitiveness, the existence of many shortcomings has prevented foreign investment from disseminating and amplifying these effects. After the start of the transition of these countries to a market economy (1990), FDI inflows were relatively modest at first, from 2003 onwards increasing dramatically until 2009 and contributing substantially to gross fixed capital formation (in Slovakia with over one third of gross formation of fixed capital between 2000-2007, in Bulgaria with over 50\% of it between 2000-2008 etc.). In these 
countries, until 2008, there was a close correlation between the volume of FDI inflows and GDP growth, after which FDI fell sharply, while the decline in GDP was much lower. The detailed analysis of the evolution of the two indicators shows that the inflow of FDI at a given time is soon followed by the increase in GDP and GDP / capita, which highlights the positive role of FDI as a driver of economic growth.

The inflow of FDI also had effects on the use of labor in these countries: in the period 19902005 , when the inflow gradually increased, the unemployment rate was raised as a result of the restructuring of enterprises, a hard process because in those countries, under the planned economy regime, public enterprises had overstaffed by virtue of the requirement of a socialist economy for the full use of available labor; after 2005 to 2008, when the inflow of FDI peaked, unemployment was at a low level following the completion of business restructuring actions; in the period 2008-2015, the evolution of the unemployment rate correlated with that of FDI, which shows, in general, that the influx of FDI determines the reduction of unemployment.

FDI also significantly influence the changes in the institutional framework of the host country, although the impact is not direct: FDI enters these countries on the basis of institutional arrangements designed to protect them from expropriation or corruption and ensure their profitability, which in turn increases political pressure in the host country to improve its institutional framework. Based on the aggregate quality indicator of the institutional framework designed by the European Bank for Reconstruction and Development (which includes transition-specific indicators on governance - policies on liberalization, privatization, trade links, exchange rate regime and competition), the quoted author shows that between $1990-2000$ improvements in the institutional framework in the group of future Member States of the European Union have paved the way for the intensification of the inflow of FDI, which is growing strongly, as mentioned above. This demonstrates that the improvement of the institutional framework causes, with a certain delay, the increase of the FDI inflow and, implicitly, the increase of their effects.

Other indirect effects of FDI on the labor market highlighted in the cited study were (Estrin, Hanousek, Kocenda, Svejnar, 2009; Estrin, Uvalio, 2014): privatization in favor of foreign investors produced $50 \%$ more restructuring than that achieved with domestic managers or workers, which shows that FDI was, through privatization, a factor which has strongly boosted business restructuring, initially contributing to the rise in the unemployment rate but leading to a long-term increase in production and a reduction in that rate; labor mobility ensures the dissemination in the economy of professional skills and know-how from FDI companies to other domestic companies, the demonstration effect being an effective vector for the dissemination of knowledge.

The effects of FDI on R\&D activities in Central and Eastern European countries were mixed: out of five studies that addressed this topic, three showed positive effects and two found negative externalities of FDI (Meyer, Sinani). The essential elements that prevent the existence of more positive externalities in terms of these activities are the large technological gap between the host country and the scientific and technological potential of foreign investors, the inferior quality of existing human capital and the institutional framework, all this leading to a reduced capacity of the host country for technological and know-how absorption.

The review of other studies on the effects of FDI on the economies of the Member States of the European Union can go on. However, the conclusions of the presented studies are clear: the mentioned effects can be both positive and negative on the economy and economic sectors, insofar as they are prepared to effectively absorb production technologies, professional skills, training and managerial capacity brought by foreign investments of strategic investors; the existence of significant shortcomings in the location advantages presented by countries to foreign investors is a strong deterrent to them and a reduction in the potential positive effects of FDI; policies to stimulate the attraction of FDI by improving the location benefits offered, first 
of all to increase the quality of human capital and the institutional framework, have the decisive role in amplifying the positive effects of FDI.

\section{Conclusions}

The investment policy of the European Union has progressively crystallized, going from initial provisions formulated in general terms to some more rigorous ones and with more and more precise application mechanisms.

The key objective consistently pursued in this development over six decades has been to ensure a unitary and at the same time flexible character of investment policy as a component of the Union's industrial policy.

After 2017, the European Union has become more cautious in its investment policy with regard to FDI which targets strategic, sensitive sectors in the economies of member countries and can threaten their economic and financial security.

Consistent pursuit of this evolving policy has ensured substantial inflows and outflows of FDI over the years. The effects of FDI inflows on member countries have been the subject of studies whose findings have sometimes proved to be divergent. For the countries of Central and Eastern Europe, which became members of the European Union after 2004, the positive effects were predominant, manifesting themselves on multiple levels such as economic growth expressed in terms of GDP or GDP / inhabitant, labor productivity growth, unemployment rate reduction, intensifying and improving the export structure, etc.

\section{References}

1. *** Public consultation on modalities for investment protection and Investor - State Settlement. Dispute in Transatlantic Trade and Investment Partnership, March 27, 2014. Available on: http://trade.ec.europa.eu/doclib/docs/2014/marchtradoc 152280.pdf.

2. Bevan, A.A. and Estrin, S. (2004). The Determinants of Foreign Direct Investment into European Transition Economies, Journal of Comparative Economics, vol. 32 n4, pp.775-87.

3. Biswas, R. (2002). Determinants of foreign direct investment, Review of Development Economics, 6 (3), pp. 492-504.

4. Blomstrom, M., Lipsey, R.E. and M. Zejan, M. (1994). What Explains Developing Country Growth, NBER Working Paper No. 4132, NBER, Cambridge, MA.

5. Botric,V., Skulic. L. (2005). Main Determinants of Foreign Direct Investment in the South East European Countries. Trade, FDI and Relocation: Challenge for Employment and Growth in the European Union, 2nd Euroframe Conference on Economic Policy Issues in the European Union, Vienna.

6. Estrin S., and Uvalio, M. (2014). FDI into transition economies: Are the Balkans different. Economics of Transition, 22:2, pp.281-312.

7. Estrin, S. (2017). Foreign direct investment and employment in transition economies. Has FDI into transition countries had the expected economic effects.: IZA World of Labor, 330.

8. Estrin, S., Hanousek, J., Kocenda, E., and Svejnar, J. (2009). The effect of privatisation and ownership in transition economies. Journal of Economic Literature, 47:3, pp. 699-728.

9. European Commission (2019). Commission Staff Working Document on Foreign Direct Investment in the EU. Following up on the Commission Communication "Welcoming FDI While Protecting Essential Interests" of 13 September 2017, Brussels, SWD (2019) 108 final.

10. European Commission (2020a). Communication for the Commission. Guidance to the Member States concerning foreign direct investment and free movement of capital from third country, and the protection of Europe's strategic assets, ahead of the application of Regulation (EU) 2019/452 (FDI Screening Regulation, Brussels, C(2020)1981 final.

11. European Commission (2014). Press release: EU agrees rules to manage investor - state disputes, Brussels. Available at: http://europa.eu/rapid/press-release IP-14-951 en.htm?locale=en 
12. European Commission (2020b). Press release. EU FDI screening mechanism becomes fully operational, Brussels.

13. European Commission (2017). Proposal for a REGULATION OF THE EUROPEAN PARLIAMENT AND OF THE COUNCIL establishing a framework for screening of foreign direct investment into the European Union [SWD(2017)297 final], Brussels, COM(2017)487 final, 2017/0224(COD).

14. European Commission (2015). Proposal on Investment Protection and Resolution of Investment Disputes and Investment Court System in Transatlantic Trade and Investment Partnership, Available at: http://trade.ec.europa.eu/doclib/docs/2015/september/tradoc 153807-pdf.

15. Guvernul României (2019). Proiect de Ordonanță de urgență privind măsurile de punere în aplicare a Regulamentului UE 452/2019 al Parlamentului European și al Consiliului din 19 martie 2019, precum şi pentru modificarea şi completarea Legii Concurenței nr. 21/1996.

16. Meyer, K., and Sinani, E. (2009). When and where does foreign direct investment generate pozitive spillovers? A meta analysis. Journal of International Business Studies, 40:7, pp. 1075-1094.

17. Milutinovič, S.. and Stanišić, T. (2016). The effect of foreign direct investment on economic growth in the European Union. Review of International Affairs, Vol. LVII, No. 1164, October - December, pp. 106-123.

18. Mondatson, A. (2003). Foreign Direct Investment and Economic Growth in European Union, in: Journal of Economic Integration, 18 (4), pp. 689-707.

19. OECD (1962). Draft Convention on the Protection of Foreign Property, Paris.

20. Sachwald, F. (2005). The Impact of EU Enlargement on the Location of Production in Europe, Les Etudes de 1'IFRI 4 (IFRI), Paris, p.56.

21. Tang, D. (2015). Has the Foreign Direct Investment Boosted Economic Growth in the European Union Countries? Journal of International and Global Economic Studies, 8 (1), June, pp. 21-50. 